
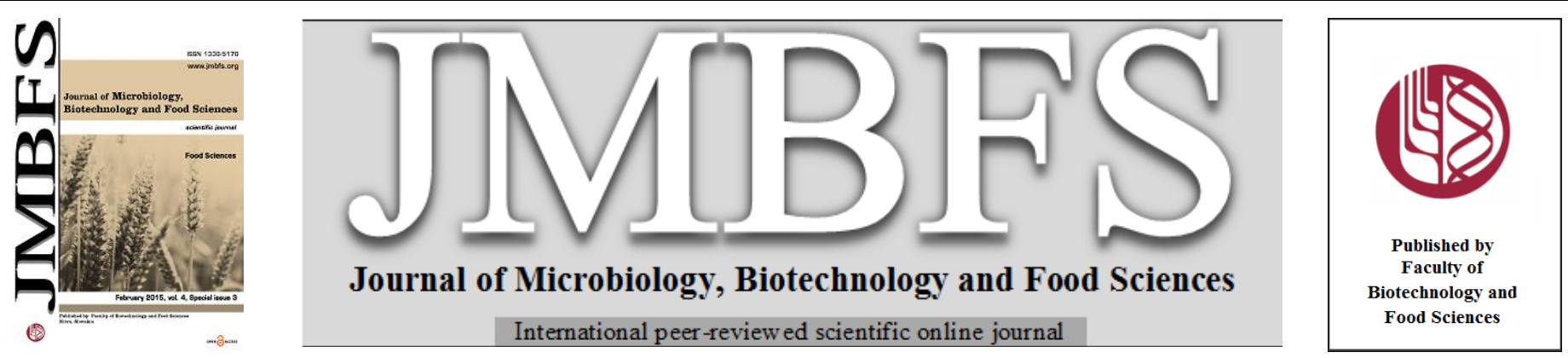

\title{
DETERMINATION OF PAHS IN COCOA SAMPLES USING D-SPE WITH DIFFERENT SORBENTS
}

\section{Anna Sadowska-Rociek*, Magdalena Surma, Ewa Cieślik}

Address(es): Dr Anna Sadowska-Rociek

University of Agriculture in Krakow, Faculty of Food Technology, Department of Nutrition Technology and Consumption, Malopolska Centre of Food Monitoring, Balicka street 122, 30-149 Krakow, Poland, +48 126624827.

*Corresponding author: a.sadowska-rociek@ur.krakow.pl

doi: 10.15414/jmbfs.2015.4.special3.135-137

\section{ART ICLE INFO}

Received 2.12.2014

Revised 7. 12.2014

Accepted 8. 12. 2014

Published 2. 2. 2015

Short communication

open $\odot$ access

\section{ABSTRACT}

The aim of this study was the determination of polycyclic aromatic hydrocarbons (PAHs) in cocoa samples by QuEChERS method preceded by the optimisation of sample preparation step using dispersive solid phase extraction (d-SPE) with different sorbents (florisil, Bond Elut ENV and $\mathrm{C}_{18}$ ) and different final methods of the extract preconcentration. The use of florisil $+\mathrm{C}_{18}+\mathrm{LLE}_{\text {gave the best results }}$ of the recovery and the cleanest ex tracts of the samples. In the study of real samples of cocoa, compounds belonging to light PAHs were mostly identified. The highest value was observed for phenanthrene $(60.04-79.04 \mu \mathrm{g} / \mathrm{kg})$ and lowest for acenaphthylene (1.83-9.79 $\mu \mathrm{g} / \mathrm{kg})$. The content of the most dangerous heavy polycyclic aromatic hydrocarbons, including P AH markers, did not exceed the limits established by EU in any of investigated samples.

Keywords: Cocoa, polycyclic aromatic hydrocarbons, QuEChERS, dispersive SPE

\section{INTRODUCTION}

Cocoa is widespread throughout the world in food industry, in cosmetics and pharmaceutical manufacturing. Cocoa beans, processed into cocoa butter and cocoa powder, are a raw material for the production of chocolate, drinks, sweets, confectionery masses and cosmetics. Cocoa beans are the source of many macroand micronut rients, including sodium, potassium, calcium, magnesium, iron and bioactive compounds such as antioxidants (Grajewska, 2006). Therefore, cocoa beans and its products may be used in the prevention of cardiovascular diseases. The compounds present in these product s have a beneficial effect on the proper function of blood vessels and prevent the development of atherosclerosis. They have the ability to inhibit the oxidation of LDL cholesterol, and reduce platelet aggregation, acting anticoagulant. Flavonols may also reduce the risk of stroke, high blood pressure. Cocoa also contains alkaloids - theobromine and caffeine, which have a stimulating effect (Kania-Lentes, 2005a,b).

Harvesting and processing of cocoa include following steps: plucking and opening the pods, fermenting and drying the cocoa seeds. During the manufacturing procedure of cocoa its liquor is roasted and winnowed, and the cocoa nibs are ground (Belitz et al., 2009). Within this manufacturing procedure there are some critical steps during which cocoa may be contaminated with polycyclic aromatichydrocarbons (PAHs). The most critical step is drying the cocoa seeds in their respective country of origin. The contamination of cocoa seeds can occur by drying cocoa on asphalt, on bitumen in the sun or by using direct drying processes (Misnawi, 2012). Furthermore, cocoa beans can be cont aminated with PAH during storage and transport in jute or sisal bags that had been treated with batching oil (Rosicka-Kaczmarek, 2006a,b).

Polycyclic aromatic hydrocarbons are a large group of organic compounds cont aining two or more conjugated aromatic rings. Among PAHs, fifteen of these compounds were recognised as mutagenic and carcinogenic by the Scientif ic Committee on Food (IARC, 2014). Their carcinogenicity is initiated by their metabolic conversion in mammalian cells to diolepoxides that bind covalently to cellular macromolecules, including DNA, causing errors in its replication and mutation. Other PAHs not defined as carcinogens may act as synergists. According to the EFSA conclusions, the sum of four PAHs (benzo[a]pyrene, benzo[a]anthracene, benzo[b]fluoranthene and chrysene) are used as a marker for the occurrence and effect of carcinogenic PAH in food (EFSA, 2008). For cocoa beans and derivative products, this sum should not exceed $35 \mu \mathrm{g} / \mathrm{kg}$, and the content of benzo[a]pyrene should not be higher than $5 \mu \mathrm{g} / \mathrm{kg}$ (Regulation 835/2011, 2011).

The aim of this study was the determination of PAHs in cocoa samples by QuEChERS method preceded by theoptimisation of sample preparation using dispersive solid phase extraction (d-SPE) with different sorbents (florisil, Bond
Elut ENV and $\mathrm{C}_{18}$ ) and different final methods of the preconcentration of the extract.

\section{MATERIAL AND METHODS}

\section{Chemicals and reagents}

Acetonitrile and hexane, HPLC grade, were purchased from MERCK KGaA, Darmstadt, Germany. Magnesium sulphate anhydrous p.a. and sodium chloride p.a., were purchased from CHEMPUR SA, Piekary Śląskie, Poland. PSA, $\mathrm{C}_{18}$ Bond Elut ENV and Bond Elut Florisil Bulk Sorbent derived from AGILENT TECHNOLOGIES, Santa Clara, USA. EPA 525 PAH Mix-B (containing 12 compounds: acenaphthylene, anthracene, benzo[a]anthracene, benzo[b]fluoranthene, benzo[k]fluoranthene, benzo[a]pyrene, chrysene, dibenzo[a,h]anthracene, fluorene, indeno[1,2,3-cd]pyrene, phenanthrene, and pyrene), chrysene- $\mathrm{d}_{12}$ (internal standard) and anthracene- $\mathrm{d}_{10}$ (syringe standard) were obtained from SUPELCO, Bellefonte, USA. Stock, intermediate and working standard solutions of compounds at concentration $1 \mu \mathrm{g} / \mathrm{mL}$ were prepared in hexane.

\section{Instrumentation}

Varian 4000 GC/MS (AGILENT TECHNOLOGIES, Santa Clara, USA) system consisted of $3800 \mathrm{GC}$ with CP-8410 aut oinjector (BRUKER, Billerica, USA) and a 4000 Ion Trap MS detector were used to conduct the GC-MS analyses. The inject or was CP-1177 Split/Splitless Capillary Injector, with a temperature of 270 ${ }^{\circ} \mathrm{C}$, and an injection volume of $1.0 \mu \mathrm{L}$. Each injection was performed in triplicate. Chromatographic separations were performed using a DB-5MS column $(30 \mathrm{~m} \mathrm{x}$ $0.25 \mathrm{~mm} \times 0.25 \mu \mathrm{m}$; AGILENT TECHNOLOGIES, Santa Clara, USA). The GC oven was operated with the following temperature program: initial temperature $50{ }^{\circ} \mathrm{C}(1.0 \mathrm{~min})-15{ }^{\circ} \mathrm{C} / \mathrm{min}-320^{\circ} \mathrm{C}(6.0 \mathrm{~min})$. Helium 5.0 (Linde Group, Munich, Germany) was used as the GC carrier gas at a flow rate of $1.0 \mathrm{~mL} / \mathrm{min}$. The ion trap mass spectrometer was operated in the internal ionisation mode, scan from $\mathrm{m} / \mathrm{z} 45$ to 500 . The emission current of the ionisation filament was set at $15 \mu \mathrm{A}$. Analyses were conducted in the selected ion monitoring mode (SIM) based on the use of one quantitative ions. Analysed compounds were identified according to their qualitative ions and retention times (Tab. 1). The trap and the transfer linetemperatures were set at 180 and $220^{\circ} \mathrm{C}$ respectively. The analyses were carried out with a solvent delay of $8.0 \mathrm{~min}$. Acquisition and processing data were performed using Varian Start Workstation software and NIST 2.0 library. 


\section{Sample preparation}

The whole experiment was divided into two parts: in the first step of the study an optimisation of the sample preparation procedure using different sorbents and preconcentration methods was made. The best variant of the method was then applied in real sample analy sis. The usefulness of the tested combinations was verified on the basis of the recovery ratio of analysed compounds (analysis of spiked samples to the level of $20 \mu \mathrm{g} / \mathrm{kg}$ ). Recovery studies involved three cocoa samples being fortified with the standard solution. The extraction procedure was thoroughly described in our previous work (Sadowska-Rociek et al., 2014a) However, in this experiment another sorbents, which could remove interferents from cocoa, were tested. In brief, the sample preparation process was based on the PAH extraction with water and acetonitrile, and separation salts $(\mathrm{NaCl}$ and $\mathrm{MgSO}_{4}$ ), followed by clean-up step by dispersive SPE using $0.15 \mathrm{gPSA}$, and 0.3 $\mathrm{g}$ of other sorbent (florisil, $\mathrm{C}_{18}$ or Bond Elut ENV). Finally, at the end of the procedure, the extracts were evaporated to dryness (evaporation, E) or liquidliquid extraction (LLE) was applied as it was invented and described previously (Sadowska-Rociek et al., 2014b). The extracts were then analysed by GC-MS. Blank samples and reagent blanks were prepared similarly but were not fortified. A series of standard solutions in hexane were prepared by dilution of the standard mixture solution at the ranges: $0.1,1,5,10,40,70$ and $100 \mathrm{ng} / \mathrm{mL}$.

\section{RESULTS AND DISCUSSION}

Method optimisation
In the first step of the experiment, three other sorbents, besides PSA, and two procedures of final extract preparation were applied in optimisation of the procedure. Primary secondary amine (PSA) removes sugars, fatty and other acids, $\mathrm{C}_{18}$, a hydrophobic sorbent, is used for removal non-polar compounds, such as fat. ENV, a PS/DVB polymer, is designed for the extraction of polar organic residues. Florisil, a magnesia-loaded silica gel, is extremely polar in nature and ideal for the isolation of polar compounds from non-polar matrices (AGILENT TEC HNO LO GIES, 2014). Taking into consideration the properties of these sorbents it was assumed that they could remove the interfering compounds from the extracts of cocoa samples, without lost of the analytes. Finally, we compared theyield of evaporation and liquid-liquid exchange step. The recoveries within 50-120\%, according to Regulation 836/2011 (2011) for all 13 compounds were observed in the variant in which $\mathrm{C}_{18}$ sorbent was used for the clean-up the extract, coupled to liquid-liquid extraction (Fig. 1.). The use of ENV did not reach the established limits of the recovery, in particular for the heaviest compounds. The application of florisil, also in the combination with LLE, resulted in similar values of recoveries to $\mathrm{C}_{18}$. However, taking into account the occurrence of the interferents on the GC-MSchromatograms, it was claimed that neither florisil nor $\mathrm{C}_{18}$ used separately, did not provide the appropriate clean-up of the extract. Thus, it was decided to combine florisil with $\mathrm{C}_{18}$ and LLE. This variant gavealso still acceptable recoveries of PAHs with the effective removal of undesirable matrix components. Finally, liquid-liquid extraction based on the exchange acetonitrile to hexane, comparing to evaporation, was another improvement of extract purification. The repeatability of recovery values, calculated as the relative standard deviation (RSD) in the spiked samples, was lower than $20 \%$ for almost all samples.

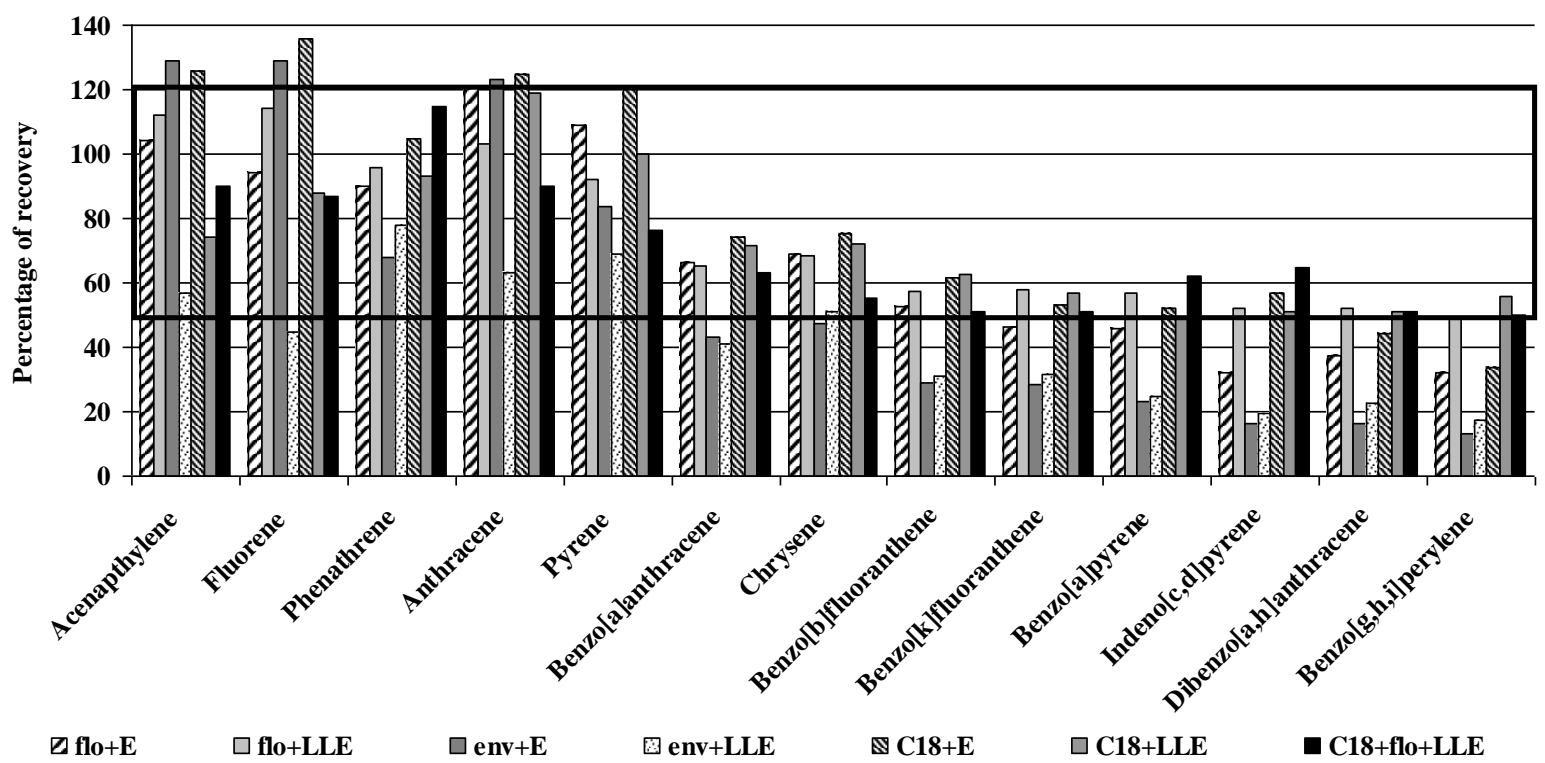

Figure 1 Recovery ratio of PAHs using various combination of sorbents (flo - florisil; E - evaporation; env - Bond Elut ENV; LLE - liquid liquid extraction)

Tab. 1 summarizes an analytical performance of the method. The values of $r$ were higher than 0.99 for all compounds. Limit of detection (LOD) and limit of quantification (LOQ) were estimated basing on the signal of the background noise measured from the chromatograms of standard at the lowest calibration level. The limit of detection was calculated as three times higher than the level of noise, and the limit of quantification were equal to three times of the detection limit. LOQs for all compounds were lower than $1 \mu \mathrm{g} / \mathrm{kg}$, except of benzo[g,h,i]perylene.

Table 1 Analytical parameters of the method

\begin{tabular}{|c|c|c|c|c|c|c|c|}
\hline Compounds & $\begin{array}{c}\text { Rt } \\
{[\mathrm{min}]}\end{array}$ & $\begin{array}{c}\text { Quantification } \\
\text { ion }\end{array}$ & $\begin{array}{l}\text { Confirmation } \\
\text { ions }\end{array}$ & $\begin{array}{c}\text { Calibration } \\
\text { slope }\end{array}$ & $\begin{array}{l}\text { Correlation } \\
\text { coefficient, } r\end{array}$ & $\begin{array}{c}\text { LOD } \\
{[\mu \mathrm{g} / \mathrm{kg}]}\end{array}$ & $\begin{array}{c}\mathrm{LOQ} \\
{[\mu \mathrm{g} / \mathrm{kg}]}\end{array}$ \\
\hline Acenapthylene & 10.128 & 152.1 & 151.1 .153 .1 & 0.011 & 0.9992 & 0.20 & 0.59 \\
\hline Fluorene & 11.243 & 166.1 & 164.1 .165 .1 & 0.007 & 0.9990 & 0.32 & 0.95 \\
\hline Phenathrene & 12.782 & 178.1 & 178.1 .179 .1 & 0.011 & 0.9995 & 0.21 & 0.63 \\
\hline Anthracene- $\mathrm{d}_{10}$ & 12.800 & 188.0 & 188.1 .177 .9 & - & - & - & - \\
\hline Anthracene & 12.835 & 178.1 & 178.1 .179 .1 & 0.011 & 0.9991 & 0.21 & 0.63 \\
\hline Pyrene & 15.059 & 202.1 & 200.1 .203 .1 & 0.012 & 0.9993 & 0.17 & 0.51 \\
\hline Benzo[a]anthracene & 17.005 & 228.1 & 226.1 .229 .1 & 0.010 & 0.9993 & 0.27 & 0.82 \\
\hline Chrysene- $\mathrm{d}_{12}$ & 17.012 & 240.1 & 228.0 .241 .0 & - & - & - & - \\
\hline Chrysene & 17.053 & 228.1 & 226.1 .229 .1 & 0.010 & 0.9991 & 0.23 & 0.69 \\
\hline Benzo[b]fluoranthene & 18.777 & 252.1 & 250.1 .253 .1 & 0.111 & 0.9989 & 0.33 & 0.99 \\
\hline Benzo[k]fluoranthene & 18.830 & 252.1 & 250.1 .253 .1 & 0.012 & 0.9989 & 0.22 & 0.67 \\
\hline Benzo[a]pyrene & 19.413 & 252.1 & 250.1 .253 .2 & 0.009 & 0.9967 & 0.27 & 0.90 \\
\hline Indeno[c,d]pyrene & 22.193 & 276.1 & 274.1 .277 .1 & 0.007 & 0.9925 & 0.27 & 0.90 \\
\hline Dibenzo[a,h]anthracene & 22.292 & 278.2 & 276.0 .279 .1 & 0.008 & 0.9912 & 0.27 & 0.90 \\
\hline Benzo[g,h,i]perylene & 22.981 & 276.0 & 274.1 .277 .0 & 0.008 & 0.9903 & 0.40 & 1.19 \\
\hline
\end{tabular}




\section{Analysis of cocoa samples}

In the second part of the study, the optimised method was used to analyse 10 samples of cocoa, available on Polish market in 2014. Preparation of the samples was performed according to the procedure described above with the application of PSA + flo $+\mathrm{C}_{18}+$ LLE. The concentrations of PAHs identified in the analysed samples were presented in Tab. 2. The total sum of PAHs ranged from 102.58 to $174.14 \mu \mathrm{g} / \mathrm{kg}$. However, this amount resulted mainly from the dominating presence of light, three-ring PAHs. In all samples only four compounds belonging to the group of PAHs were detected: acenaphthylene, fluorene, phenanthrene, and pyrene (Tab. 2). Within these compounds, the highest value was observed for phenanthrene (60.04-79.04 $\mu \mathrm{g} / \mathrm{kg}$ ) and lowest for acenaphthylene $(1.83-9.79 \mu \mathrm{g} / \mathrm{kg})$. Additionally, in six samples anthracene was detected in the ranges $1.46-12.87 \mu \mathrm{g} / \mathrm{kg}$ and chrysene and benzo[k]fluoranthene in other two samples $(10.19 \mu \mathrm{g} / \mathrm{kg}$ and $2.95 \mu \mathrm{g} / \mathrm{kg}$ respectively). Except chrysene, any PAH marker was not detected in the investigated samples. Heavier compounds, four- and five-ring PAHs, were not detected in any of the analysed sample as well. Therefore, obtained results did not exceed the levels est ablished by EU (Regulation 835/2011, 2011).

In the recent literature, the determination of PAHs in cocoa samples was studied only by Wieczorek $\boldsymbol{e t}$ al. (2002). Fluorene, fluoranthene, pyrene, and benzo[b]fluoranthene were the compounds detected most frequently, in the ranges $0.02-0.23 \mu \mathrm{g} / \mathrm{L}$. However, due to the differences in expression of the concentration units $(\mu \mathrm{g} / \mathrm{kg}$ and $\mu \mathrm{g} / \mathrm{L})$, our results and results received by these authors are difficult to compare.

Table 2 Concentration of PAHs detected in analysed samples of cocoa

\begin{tabular}{|c|c|c|c|c|c|c|c|c|c|c|}
\hline \multirow{2}{*}{ Compounds } & \multicolumn{10}{|c|}{ PAHs concentration $(\mu \mathrm{g} / \mathrm{kg})$} \\
\hline & S1 & $\mathrm{S} 2$ & S3 & $\mathrm{S} 4$ & S5 & S6 & S7 & S8 & S9 & $\mathrm{S} 10$ \\
\hline Acenapthylene & 6.77 & 6.12 & 5.98 & 6.05 & 3.67 & 9.79 & 1.83 & 7.57 & 5.30 & 3.03 \\
\hline Fluorene & 27.15 & 28.56 & 32.18 & 27.37 & 33.53 & 29.07 & 31.96 & 24.95 & 24.35 & 24.56 \\
\hline Phenathrene & 79.04 & 63.09 & 72.42 & 61.31 & 78.56 & 65.67 & 71.59 & 65.89 & 68.21 & 60.04 \\
\hline Anthracene & 0.00 & 0.00 & 12.87 & 6.95 & 3.10 & 1.46 & 6.83 & 0.00 & 7.78 & 0.00 \\
\hline Pyrene & 43.49 & 43.55 & 38.52 & 43.47 & 50.45 & 48.64 & 51.73 & 42.65 & 14.78 & 14.95 \\
\hline Benzo[a]anthracene & 0.00 & 0.00 & 0.00 & 0.00 & 0.00 & 0.00 & 0.00 & 0.00 & 0.00 & 0.00 \\
\hline Chrysene & 0.00 & 0.00 & 0.00 & 0.00 & 0.00 & 0.00 & 10.19 & 0.00 & 0.00 & 0.00 \\
\hline Benzo(b)fluoranthene & 0.00 & 0.00 & 0.00 & 0.00 & 0.00 & 0.00 & 0.00 & 0.00 & 0.00 & 0.00 \\
\hline Benzo(k)fluoranthene & 0.00 & 0.00 & 2.95 & 0.00 & 0.00 & 0.00 & 0.00 & 0.00 & 0.00 & 0.00 \\
\hline Benzo[a]pyrene & 0.00 & 0.00 & 0.00 & 0.00 & 0.00 & 0.00 & 0.00 & 0.00 & 0.00 & 0.00 \\
\hline Indeno[c,d]pyrene & 0.00 & 0.00 & 0.00 & 0.00 & 0.00 & 0.00 & 0.00 & 0.00 & 0.00 & 0.00 \\
\hline Dibenzo[a,h]anthracene & 0.00 & 0.00 & 0.00 & 0.00 & 0.00 & 0.00 & 0.00 & 0.00 & 0.00 & 0.00 \\
\hline Benzo[g,h,i]perylene & 0.00 & 0.00 & 0.00 & 0.00 & 0.00 & 0.00 & 0.00 & 0.00 & 0.00 & 0.00 \\
\hline Total sum of PAHs & 156.44 & 141.32 & 164.92 & 145.15 & 169.31 & 154.62 & 174.14 & 141.06 & 120.42 & 102.58 \\
\hline
\end{tabular}

Legend: S - sample

\section{CONCLUSION}

In general, a modification of QuEChERS method for PAH determination in cocoa samples has been proposed. During the method optimisation it was found that the use of PSA + florisil $+\mathrm{C}_{18}+$ LLE gave the best results of the recovery and the cleanest extracts of the samples. In the study of real samples of cocoa, compounds belonging to light PAHs were mostly identified. The content of the most dangerous heavy polycyclic aromatic hydrocarbons, including $\mathrm{PAH}$ markers, did not exceed the limits established by EU in any of investigated samples.

Acknowledgments: This research was performed with the financial support of the University of Agriculture in Krakow for young scientists and doctoral students (grant for Dr Anna Sadowska-Rociek, no. BM-4778/KT GiK/2014), which is hereby gratefully acknowledged.

\section{REFERENCES}

AGILENT TECHNOLOGIES. 2014. Agilent Products for Solid Phase Extraction Brochure. Agilent Technologies www.chem.agilent.com.

BELITZ,H.-D., GROSCH, W., SCHIEBERLE, P. 2009. Coffee, tea, cocoa. [In] Food Chemistry. Berlin: Springer, 938-970. ISBN 978-3-540-69934-7, http://dx.doi.org/10.1007/978-3-662-07279-0_22.

COMMISSION REGULATION (EU) No 835/2011 of 19 August 2011 amending Regulation (EC) No $1881 / 2006$ as regards maximum levels for polycyclic aromatic hydrocarbons in foodstuffs.

COMMISSION REGULATION (EU) No 836/2011 of 19 August 2011 amending Regulation (EC) No 333/2007 laying down the methods of sampling and analysis for the official control of the levels of lead, cadmium, mercury, inorganic tin, 3 $M C P D$ and benzo(a)pyrene in foodstuffs.

EFSA. 2008. Findings of the EFSA data collection on polycyclic aromatic hydrocarbons in food. A report from the unit of data collection and exposure on a request from the European Commission. EFSA, http://www.efsa.europa.eu/en/efsajournal/doc/33r.pdf
GRAJEWSKA, D., MYSZKOWSKA-RYCIEK, J. 2006. Chocolate - sweet delicacy or medicine? Catering Review, 5, 26-27.

IARC. 2014. IARC Monographs on the Evaluation of Carcinogenic Risks to Humans. VOLUME 92 Some Non-heterocyclic Polycyclic Aromatic Hydrocarbons and Some Related Exposures. IARC, http://www.iarc.fr.

KANIA-LENTES, P., 2005. From the cocoa bean to chocolate. Part I. Bakery and Confectionery Review, 10, 62-63.

KANIA-LENTES, P.,2005. From the cocoa bean to chocolate. Part II. Bakery and Confectionery Review, 11, 68-69.

MISNAWI, 2012. Effect of cocoa bean drying methods on polycyclic aromatic hydrocarbons contamination in cocoa butter. International Food Research Journal, 19(4), 1589-1594.

ROSICKA-KACZMAREK, J. 2006. Changes of selected physical and chemical properties of cocoa beans during its processing (part II). Bakery and Confectionery Review, 9, 66-68.

ROSICKA-KACZMAREK, J. 2006. Changes of selected physical and chemical properties of cocoa beans during its processing (part III). Bakery and Confectionery Review, 10, 60-65.

SADOWSKA-ROCIEK, A., SURMA, M., CIEŚLIK, E. 2014a. Comparison of different modifications on QuEChERS sample preparation method for PAHs determination in black, green, red and white tea. Environmental Science and Pollution Research, 2014,21(2), 1326-1338, http://dx.doi.org/10.1007/s11356013-2022-1.

SADOWSKA-ROCIEK, A., SURMA, M., CIEŚLIK, E. 2014b. Determination of polycyclic aromatic hydrocarbons in coffee and coffee substitutes using dispersive SPE and gas chromatography-mass spectrometry. Food Analytical Methods, http://dx.doi.org/10.1007/s12161-014-9876-9.

WIECZOREK, J., MOZOLEWSKI, W., SMOCZYŃSKA, K., WIECZOREK, Z. 2002. The occurrence of polycyclic aromatic hydrocarbons (PAHs) in infusion of natural coffee, coffee substitute and cocoa. Annals of National Institute of Hygiene, 53, 231-236. 